\title{
The Detritus Nitrogen Problem: New Observations and Perspectives from Organic Geochemistry
}

\author{
Donald L. Rice* \\ Skidaway Institute of Oceanography, P. O. Box 13687, Savannah, Georgia 31406, USA
}

\begin{abstract}
Studies of the decompositional chemistry of 5 types of estuarine macrophyte detritus were undertaken to examine relations among detrital nitrogen, protein, and other decompositional products. Protein and nitrogen contents of the detritus correlated poorly. Although the total mass of protein in all detritus decreased after $150 \mathrm{~d}$ of aging, there was a net increase in the mass of detrital nitrogen in some vascular plant detritus. During decomposition, detritus becomes richer in reactive phenolic and carbohydrate groups which may form condensation products with amino acids, yielding precursors to complex nitrogenous humic geopolymers. The existence of a significant positive relation between nitrogen accumulation and the production of humic substances suggests that much of the nitrogen accumulated during detritus decomposition is non-labile humic nitrogen rather than living microbial protein. The process of nitrogen enrichment often observed in detritus studies is consistent with the chemical behavior of nitrogen during humification. Biological availability of this humic nitrogen probably depends upon the extent to which proteinoid subunits are retained in the humic macromolecular structure.
\end{abstract}

\section{INTRODUCTION}

Since Newell's (1965) study of coprophagy by $H y$ drobia ulvae and Macoma balthica, there has been considerable speculation on the nutritional significance (to detritivores) and chemical nature of detrital nitrogen. Newell (1965) noted that freshly egested fecal pellets, originally low in nitrogen, became more nitrogen-enriched as microbial colonization of the pellets proceeded. The relatively protein-rich bacterial cells were assumed to account for the increase in $\% \mathrm{~N}$ and to be the source of nutrition to the detritivores. Subsequent studies confirmed that both nitrogen content and microbial population increase with time in detritus derived from amphipod fecal pellets (Hargrave, $1970 \mathrm{a}$, b) and from coastal macrophytes (Fell et al., 1975; Harrison and Mann, 1975; Roman, 1977). Because the nitrogen content of food is generally regarded as an important indicator of nutritional value (Russell-Hunter, 1970; Boyd and Goodyear, 1971) and because the nitrogen content of detritus is generally low, the importance of microbial 'aging' in enhancing

\footnotetext{
- Present address: Dept. of Geological Sciences and Environmental Studies, State University of New York, Binghamton, New York 13901, USA
}

the nutritional quality of detritus to macroconsumers has been emphasized (Fenchel, 1972; Mann, 1972; Hargrave, 1976).

The 'detritus nitrogen problem' has arisen because more detailed studies indicate that living microbial biomass accounts for only a small portion of the nitrogen accumulation in aged detritus. Direct counts of surface microbes on detritus particles have not yielded the numbers necessary to account for observed increases in nitrogen content with time (Wiebe and Pomeroy, 1972; Sieburth, 1975; Christian and Wetzel, 1978; Marsh and Odum, 1979). For example, surface microbes on Spartina alterniflora detritus accounted for slightly more than $3 \%$ of the nitrogen (Rublee et al., 1978). Moreover, while nitrogen accumulation in plant and fecal detritus has been attributed to proteinenrichment (as living microbial biomass), the common method of protein estimation based on measurement of total nitrogen and the application of a 6.25 conversion factor (which works rather well when applied to li v ing biomass) (Pirie, 1955) greatly overestimates the protein content of macrophyte detritus (Harrison and Mann, 1975). Although fungal biomass may sometimes account for a large portion of the excess nitrogen (Newell and Hicks, in press), this evidence collectively suggests that most of the nitrogen accumulated in 
aging detritus is not (1) in living microbes or (2) proteineous (Tenore and Rice, 1980).

A number of researchers proposed that much, if not most, of the nitrogen enrichment in detritus is present as non-living material (i. e. in the detritus matrix, not in the attached microbes). Hobbie and Lee (1980) hypothesized that mucopolysaccharides (containing 3-7 \% N) exuded by surface microbes might contribute significantly to the nitrogen increase, although the relative magnitude of this contribution is uncertain. Because of the abundance of carbohydrate and phenolic compounds in plant-derived detritus (may include fecal material and because of the reactivity of reducing carbohydrates and phenols with amino acids [Feeney and Bostock, 1958; Sieburth and Jensen, 1969, Feeney, 1970]), a significant amount of detrital nitrogen may exist as protein-carbohydrate and/or proteinphenol condensation products in the detritus matrix itself (Suberkropp et al., 1976; Odum et al., 1979; Rice, 1979). Such products are precursors of nitrogenous humic geopolymers found in seawater and in modern and ancient sediments (Degens and Reuter, 1962; Sieburth and Jensen, 1969).

To complement recent studies of the decompositional chemistry of detritus derived from a variety of estuarine macrophytes (Rice and Tenore, 1981), we have attempted to relate the temporal changes in nitrogen contents of 5 types of macrophyte detritus to concomitant changes in detrital protein, reactive carbohydrate, reactive phenolic, and bulk 'humic' (dark-colored, alkali-soluble, polycondensed organic) contents. The 5 detritus selected for this study were chosen to represent a variety of sources (2 macroalgae, 1 seagrass, 1 marsh grass, and 1 mangrove) and to cover the spectrum of relative decomposability and tendency to accumulate nitrogen. Drawing on evidence from organic geochemical studies of marine and lacustrine detritus and sediments, we propose a mechanism for nitrogen accumulation in detritus and a working hypothesis for further study of the detritus nitrogen problem.

\section{MATERIALS AND METHODS}

\section{Aging of Detritus}

Detritus derived from 2 macroalgae - Gracilaria foliifera (Harvey) Taylor and Spatoglossum schroederi (C. Agardh) - and from dead leaves of turtle grass Thalassia testudinum Koenig and Sims, smooth cordgrass Spartina alterniflora Loisel, and red mangrove Rhizophora mangle Linnaeus were lyophilized and ground to pass a 40-mesh sieve. Twelve 10 -g samples of each of the 5 detritus were placed into 12 clean glass jars (height $17.5 \mathrm{~cm}$, mouth $6.2 \mathrm{~cm}, 950 \mathrm{ml}$ brim capac- ity) and submerged in a $610 \mathrm{l}$ flow-through tank receiving $5 \mu \mathrm{m}$-filtered seawater from the Skidaway River. The submerged detritus types were allowed to decompose in the absence of light for up to 6 mo (August 1978 through early January 1979). After 5, 10, 25, 50, 100, and $150 \mathrm{~d}$ of aging, 2 jars of each detritus were removed and the residual detritus was lyophilized, weighed, and analyzed for carbon, nitrogen, protein, reactive carbohydrate, reactive phenol, and humic content as described below. Details of the collection and preparation of detritus and of the experimental design and equipment have been presented elsewhere (Rice and Tenore, 1981).

\section{Carbon, Nitrogen and Ash}

Percent carbon and nitrogen were determined on triplicate detritus samples from each jar (6 determinations for each detritus-age combination) using a Perkin-Elmer Model 240 Elemental Analyzer. Comparison of detritus samples treated with $0.1 \mathrm{~N} \mathrm{HC1}$ with untreated samples indicated that carbonate-carbon contributed insignificantly to the carbon contents of all detritus stocks.

Ash content and percent ash-free dry weight were determined by measurement of weight loss after combustion in a muffle furnace at $550^{\circ} \mathrm{C}$ for $16 \mathrm{~h}$.

\section{Preteatment for Biochemical Assays}

Prior to determinations of protein, reactive carbohydrate, reactive phenol, and humic content, all detritus were extracted with $5: 1 \mathrm{v} / \mathrm{v}$ chloroform-methanol $\left(22^{\circ} \mathrm{C} \pm 1 \mathrm{C}^{\circ}, 8 \mathrm{~h}\right)$ to remove traces of interfering lipids and hydrophobic pigments. Detritus was recovered by vacuum filtration through Whatman No. 1 filter discs. After most of the solvent had been drawn off, $10 \mathrm{ml}$ of chloroform-methanol were added to the detritus in the filtration apparatus to rinse away residual hydrophobic material. The moist extracted detritus was cooled to $-20^{\circ} \mathrm{C}$ and excess solvent was drawn off under vacuum. The extracted detritus was weighed (mass losses were less than $0.5 \%$ ) and stored in a laboratory freezer until needed for the analyses described below.

\section{Protein}

Protein was extracted by dilute alkaline hydrolysis and estimated by the method of Lowry et al. (1951) modified to compensate for interference by phenols. The Lowry technique is based on the ability of (1) the amino acids tryptophan and tyrosine, and (2) certain 
protein-cupric ion complexes to reduce the yellow phosphomolybdic-phosphotungstic complexes in the Folin reagent to a blue end product which may be read colorimetrically. Phenolic compounds also reduce the Folin reagent and will interfere in Lowry protein determinations. However, cupric ion added to increase protein reducing power has no effect upon the reduction by tryptophan and tyrosine or by phenols. Consequently, in the presence of phenols, protein may be estimated colorimetrcally by substracting absorbances obtained in a Lowry procedure without copper addition from absorbances obtained in the usual Lowry procedure in which reducing protein-copper complexes are formed by addition of a cupric sulfate reagent.

To extract protein, $0.25 \mathrm{~g}$ samples of detritus were extracted in $50.0 \mathrm{ml}$ of near-boiling $0.5 \mathrm{~N}$ sodium hydroxide for $1 \mathrm{~h}$. Extractions were carried out in a nitrogen atmosphere to prevent oxidative condensation reactions of polypeptides, phenolic compounds, and carbohydrates which are deeply colored and interfere with colorimetric determinations (Degens and Reuter, 1962). The alkali extracts were cooled to room temperature under nitrogen, transferred to centrifuge tubes, and diluted to $10.0 \mathrm{ml}$ with $0.5 \mathrm{~N}$ sodium hydroxide. The tubes were immediately stoppered and centrifuged until the liquid was clear.

Separate aliquots of protein extract were carried through the Lowry et al. (1951) procedure with and without the addition of copper sulfate. Briefly, $100 \mu \mathrm{l}$ of protein extract were added to $900 \mu \mathrm{l}$ redistilled water in a test tube. One $\mathrm{ml}$ of alkaline copper solution (made by mixing $20 \mathrm{ml}$ of $10 \%$ sodium carbonate in 1 $\mathrm{N}$ sodium hydroxide, $1 \mathrm{ml}$ of $2 \%$ potassium tartrate, and $1 \mathrm{ml}$ of $1 \%$ cupric sulfate) was added to the test tube; the contents were mixed and allowed to stand for $10 \mathrm{~min}$. Three $\mathrm{ml}$ of diluted Folin reagent (made by diluting $1 \mathrm{ml}$ of the commercial $2 \mathrm{~N}$ reagent with $10 \mathrm{ml}$ of redistilled water) were then added and the contents were mixed quickly. The reaction mixture was allowed to stand for 30 min to permit maximum color development and absorbance was read at $750 \mathrm{~nm}$ against a reagent blank. The entire procedure was repeated with other $100 \mu \mathrm{l}$ aliquots except that the alkaline copper reagent was replaced by an alkaline reagent (no cupric sulfate).

Differences in absorbances at $750 \mathrm{~nm}$ were related to protein concentration using bovine serum albumin as the protein standard. Absorbance differences between copper-containing and copper-free blanks were not detectable $(<0.01$ absorbance units). Like the ordinary Lowry method, this procedure yielded a nonlinear relationship between protein concentration and absorbance (Table 1). Although absorbances obtained with copper-complexed samples were always signifi-
Table 1. Calibration of the modified Lowry protein method with bovine serum albumin (BSA). Relative absorbances of the reduced Folin reagent are given with copper addition (usual Lowry procedure), without copper addition, and as the difference in the 2 absorbances. The latter value is used for protein estimation in matrices containing reducing phenois

\begin{tabular}{|c|c|c|c|}
\hline \multirow{2}{*}{$\begin{array}{c}\text { BSA } \\
\text { Concentration } \\
(\mu \mathrm{g} \text { BSA } / 100 \mu \mathrm{l} \\
\text { extract })\end{array}$} & \multicolumn{3}{|c|}{ Absorbance at $750 \mathrm{~nm}$} \\
\hline & $\begin{array}{l}\text { With } \\
\mathrm{Cu}^{2+}\end{array}$ & $\begin{array}{c}\text { Without } \\
\mathrm{Cu}^{2+}\end{array}$ & $\begin{array}{c}\Delta \text { Absor- } \\
\text { bance }\end{array}$ \\
\hline 2.5 & $0.07 \pm 0.01$ & $0.01 \pm 0.01$ & $0.06 \pm 0.01$ \\
\hline 5.0 & $0.12 \pm 0.01$ & $0.02 \pm 0.01$ & $0.10 \pm 0.01$ \\
\hline 10.0 & $0.25 \pm 0.02$ & $0.04 \pm 0.01$ & $0.21 \pm 0.02$ \\
\hline 25.0 & $0.53 \pm 0.03$ & $0.09 \pm 0.02$ & $0.44 \pm 0.03$ \\
\hline
\end{tabular}

cantly greater than without copper addition, the more lignous (and presumably more phenol-rich) detritus gave absorbances without copper addition that accounted for as much as $40 \%$ of the absorbance with copper addition (Table 2). Although this procedure

Table 2. Phenolic interference in the determination of protein in 150-d macrophyte detritus by the modified Lowry method. Interference was greatest in Rhizophora mangle extracts and least in Gracilaria foliffera extracts

\begin{tabular}{|lc|}
\hline $\begin{array}{l}\text { 150-d old } \\
\text { detritus }\end{array}$ & Ratio \\
\cline { 2 - 2 } & Absorbance without $\mathrm{Cu}^{2+}$ addition \\
\hline Gracilaria foliifera & 4.0 \\
Spatoglossum schroederi & 2.6 \\
Thalassia testudinum & 2.1 \\
Spartina alterniflora & 1.7 \\
Rhizophora mangle & 1.5 \\
\hline
\end{tabular}

provides precision better than $4 \%$, the usual problems of accuracy associated with the Lowry et al. (1951) method (arising from differences in compositions of different proteins) restrict sample-to-sample comparisons to determinations on the same detritus (Rice, 1979).

\section{Carbohydrate, Phenols and Humic Matter}

Particulate reactive carbohydrate was estimated by the method of Strickland and Parsons (1972), except that the phenol-sulfuric acid reagent (Dubois et al., 1956) was substituted for the anthrone reagent. The assay depends upon the presence of reducing saccharides and should not be interpreted as a determination of "total carbohydrate". For convenience, weight percent reactive carbohydrate was recorded as $\alpha$-D. glucose equivalents. 
Phenols were extracted from $0.25 \mathrm{~g}$ samples of detritus with $10 \mathrm{ml}$ of $50 \% \mathrm{v} v$ methanol water at $50{ }^{\circ} \mathrm{C}$ for $3 \mathrm{~h}$ (Suberkropp et al., 1976). Before sealing the extraction vessels, the system was flushed with helium to inhibit oxidative reactions of extracted phenols. Reducing capacity of extractable phenols was determined by reaction with the Folin-Ciocalteau reagent using a modification of the procedure of King and Heath (1967). Briefly, $100 \mu \mathrm{l}$ aliquots of extractant solution were added to $100 \mu \mathrm{l}$ of $2 \mathrm{~N}$ Folin-Ciocalteau reagent, and the mixture was allowed to stand for 3 min. Then $3 \mathrm{ml}$ of saturated aqueous sodium carbonate was added, the vessel was flushed with helium and sealed, and the mixture was allowed to stand for $1 \mathrm{~h}$ with occasional shaking. Absorbance of the blue solution was read at $725 \mathrm{~nm}$ (1-cm cell length) against a reagent blank. Because plant tissues contain complex mixtures of a variety of phenolic compounds which vary widely between species (Harborne, 1964; Ragan and Craigie, 1978), this procedure measures the overall reducing capacity of a suite of phenolic compounds, not the concentration per se. Reactive phenolic contents below are reported as \% equivalent phenol $\left(\mathrm{C}_{6} \mathrm{H}_{5} \mathrm{OH}\right)$ in ash-free detritus.

Alkali-soluble humic substances (humic and fulvic acids) were assayed after extraction by non-oxidative alkaline hydrolysis (Degens and Reuter, 1962); $0.5 \mathrm{~g}$ of detritus and $50 \mathrm{ml}$ of helium-purged $0.2 \mathrm{~N}$ sodium hydroxide were placed into $125 \mathrm{ml}$ flasks, and after vigorously bubbling helium through the mixture for 3 min, the flasks were stoppered and sealed with paraffin. Flasks were shaken constantly for $24 \mathrm{~h}$ at a temperature of $20^{\circ} \mathrm{C} \pm 1 \mathrm{C}^{\circ}$ and then allowed to stand for $1 \mathrm{~h}$.
The supernatant liquid was transferred to capped glass centrifuge tubes and centrifuged until clear. Absorbance of the yellow to brown colored solution was immediately read at $425 \mathrm{~nm}$ against a $0.2 \mathrm{~N}$ sodium hydroxide blank. Percent humic content was calculated using humic acid from the Satilla River, Georgia, as the analytical standard.

\section{Statistics}

All chemical compositions reported in this paper are averages of 6 independent determinations 3 separate determinations per jar of detritus X 2 jars for each aging time) \pm 1 standard deviation and are given as percent of ash-free dry weight.

Student's statistics were used to assess significance of compositional changes with time. Correlation analysis of the data was accomplished by comparing linear correlation coefficients with coefficients from a statistically uncorrelated population (Bevington, 1969). In the analysis of data, statistical significance was assumed at the $95 \%$ confidence level $(p \leq 0.05)$.

\section{RESULTS}

A summary of the carbon-nitrogen chemistry (ashfree $\% \mathrm{C}$ and $\% \mathrm{~N}$ ) and decomposability (\% of original ash-free dry weight remaining after $150 \mathrm{~d}$ aging) of the 5 detritus types is included in Table 3. Details of the temporal variations in $\% \mathrm{C}, \% \mathrm{~N}$, and detritus mass have been presented in another report (Rice and Tenore, 1981).

Table 3. Chemical composition (\%) of original (Day 0) and final (Day 150) macrophyte detritus

\begin{tabular}{|c|c|c|c|c|c|c|c|}
\hline \multicolumn{8}{|c|}{ Chemical composition (percent of ash-free dry weight) } \\
\hline & Carbon & Nitrogen & Protein & $\begin{array}{c}\text { Reactive } \\
\text { carbohydrate }\end{array}$ & $\begin{array}{l}\text { Reactive } \\
\text { phenols }\end{array}$ & $\begin{array}{c}\text { Extractable } \\
\text { humic } \\
\text { material }\end{array}$ & $\begin{array}{l}\% \text { of original } \\
\text { ash-free dry } \\
\text { weight present }\end{array}$ \\
\hline \multicolumn{8}{|l|}{ Gracilaria foliifera } \\
\hline Detritus $\mathrm{t}=0$ & $47.2 \pm 4.0$ & $3.01 \pm 0.04$ & $11.2 \pm 0.1$ & $32 \pm 1$ & $0.7 \pm 0.2$ & $0.29 \pm 0.01$ & $(100)$ \\
\hline Detritus $t=150$ & $42.1 \pm 0.6$ & $2.89 \pm 0.4$ & $18.1 \pm 0.1$ & $33 \pm 1$ & $1.4 \pm 0.0$ & $0.62 \pm 0.01$ & $48 \pm 1$ \\
\hline \multicolumn{8}{|c|}{ Spatoglossum schroederi } \\
\hline Detritus $\mathrm{t}=0$ & $51.3 \pm 0.1$ & $3.29 \pm 0.16$ & $16.1 \pm 0.4$ & $7.3 \pm 0.6$ & $2.1 \pm 0.1$ & $1.39 \pm 0.01$ & $(100)$ \\
\hline Detritus $\mathrm{t}=150$ & $49.2 \pm 0.8$ & $6.13 \pm 0.21$ & $24.0 \pm 0.4$ & $6.7 \pm 0.5$ & $4.1 \pm 0.1$ & $3.81 \pm 0.31$ & $52 \pm 3$ \\
\hline \multicolumn{8}{|c|}{ Thalassia testudinum } \\
\hline Detritus $\mathrm{t}=0$ & $47.0 \pm 0.5$ & $2.76 \pm 0.09$ & $14.3 \pm 0.1$ & $15 \pm 1$ & $4.4 \pm 0.1$ & $3.11 \pm 0.02$ & $(100)$ \\
\hline Detritus $\mathrm{t}=150$ & $44.4 \pm 2.3$ & $2.92 \pm 0.20$ & $11.5 \pm 0.1$ & $24 \pm 1$ & $4.0 \pm 0.1$ & $2.60 \pm 0.09$ & $88 \pm 2$ \\
\hline \multicolumn{8}{|l|}{ Spartina alterniflora } \\
\hline Detritus $\mathrm{t}=0$ & $47.9 \pm 0.2$ & $0.46 \pm 0.01$ & $2.6 \pm 0.1$ & $13 \pm 1$ & $13.8 \pm 1.4$ & $4.90 \pm 0.04$ & $(100)$ \\
\hline Detritus $\mathrm{t}=150$ & $47.3 \pm 0.1$ & $0.70 \pm 0.07$ & $2.9 \pm 0.1$ & $22 \pm 1$ & $13.3 \pm 0.5$ & $4.69 \pm 0.07$ & $77 \pm 8$ \\
\hline \multicolumn{8}{|l|}{ Rhizophora mangle } \\
\hline Detritus $t=0$ & $50.4 \pm 0.2$ & $1.18 \pm 0.01$ & $6.5 \pm 0.1$ & $21 \pm 1$ & $17.1 \pm 0.8$ & $17.7 \pm 0.2$ & $(100)$ \\
\hline Detritus $\mathrm{t}=150$ & $54.3 \pm 1.3$ & $2.11 \pm 0.04$ & $7.7 \pm 0.4$ & $24 \pm 1$ & $17.4 \pm 0.1$ & $18.6 \pm 0.2$ & $81 \pm 3$ \\
\hline
\end{tabular}


During aging, nitrogen concentration increased significantly in all detritus types, except that obtained from Gracilaria foliifera (Fig. 1). After $150 \mathrm{~d}, \mathrm{~N}$ concentrations in ash-free detritus were about $80 \%$ higher in Spatoglossum schroederi and Rhizophora mangle, $50 \%$ higher in Spartina alterniflora and $6 \%$ higher in Thalassia testudinum than in the initial detritus. Temporal variations in the absolute mass of detrital $N$ (Fig. 2) indicated that for $R$. mangle and $S$ alterniflora, increases in $\% \mathrm{~N}$ were attributable to net tranfers of $\mathrm{N}$ from seawater to detritus. Increases in $\% \mathrm{~N}$ in $S$. schroederi and $T$. testudinum occurred although the final mass of $\mathrm{N}$ in $\mathrm{S}$. schroederi was not significantly

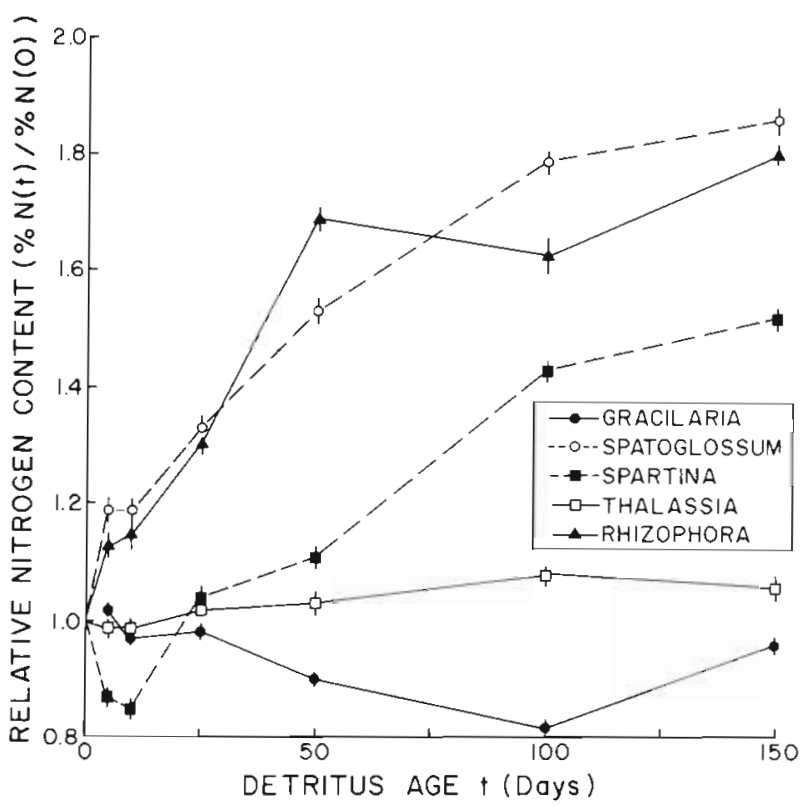

Fig. 1. Nitrogen content of macrophyte detritus during decomposition. For each detritus, \% $\mathrm{N}$ (ash-free basis) is normalized to initial (Day 0) \% $\mathrm{N}$ listed in Table 3

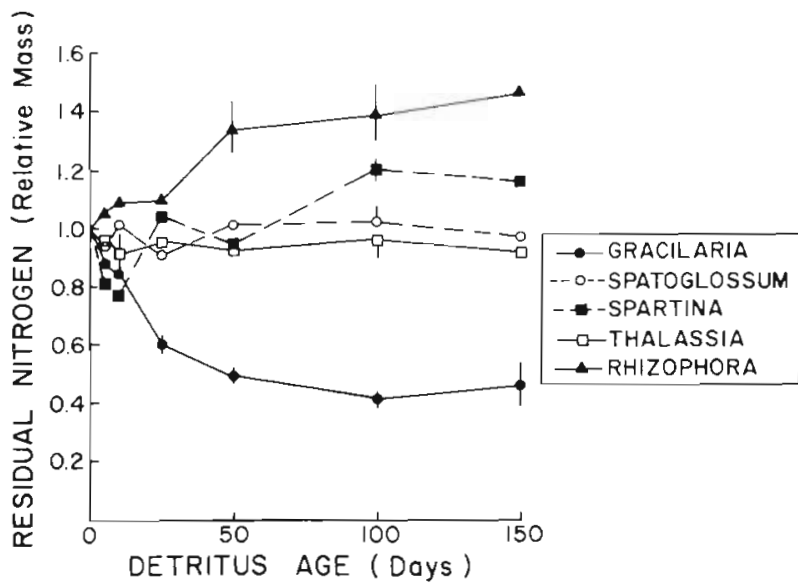

Fig. 2. Absolute mass of detrital nitrogen during decomposition. For each detritus, nitrogen mass calculated from $\% \mathrm{~N}$ and residual ash-free dry weight is normalized to initial (Day 0) nitrogen mass. (Adapted from Rice and Tenore, 1981) different than on Day 0 , and the final mass of $N$ in $T$. testudinum was significantly less than on Day 0 . The absolute mass of $\mathrm{N}$ in $G$. foliifera detritus decreased significantly through Day 100 and then appeared to increase slightly (Fig. 2); this pattern of variation in $\mathrm{N}$ mass accounts for the significant decrease in $\% \mathrm{~N}$ through Day 100 and the incipient increase during the final third of the aging experiment (Fig. 1). The net changes in \% $N$ from Day 0 to Day 150 $(\triangle \% \mathrm{~N}=\% \mathrm{~N}(\mathrm{t}=150)-\% \mathrm{~N}(\mathrm{t}=0))$ decreased in the order $S$. schroederi $(+2.84 \%)>R$. mangle $(+0.93 \%)>$ S. alterniflora $(+0.24 \%)>T$. testudinum $(+0.16 \%)>$ G. foliifera $(-0.12 \%)$.

Changes in the protein content of the detritus are shown in Fig. 3. There was generally an increase in \%

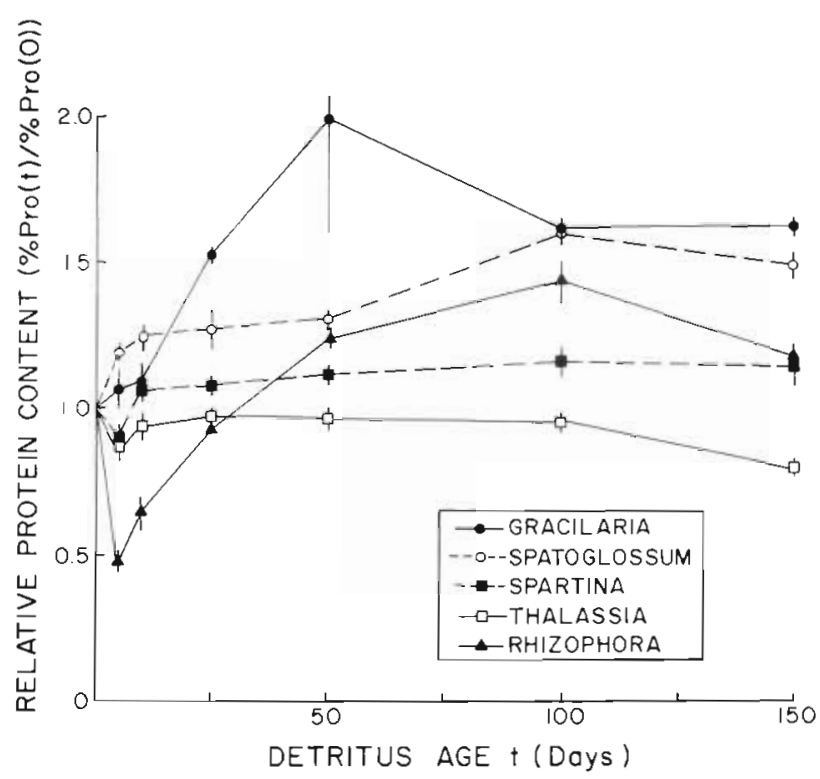

Fig. 3. Protein content of macrophyte detritus during decomposition. For each detritus, \% protein (ash-free basis) is normalized to initial (Day 0) \% N listed in Table 3

extractable protein for the first 50 to $100 \mathrm{~d}$ followed by a decrease in the last 50-150 d. Conversely, in $T$. testudinum detritus, $\%$ extractable protein dropped below the initial value within $10 \mathrm{~d}$ and then changed insignificantly except for a decrease during the last $50 \mathrm{~d}$ of decomposition. Maximum values of \% protein were attained earliest in the more readily decomposed and latest in the most decay-resistant detritus (c. f. Fig. 1; Table 3, Column 9). Although the absolute mass of protein varied significantly and sometimes erratically (Fig. 4), there was less protein in each jar at the end of the experiment than initially, even in those cases where the absolute mass of nitrogen either increased or remained constant (Fig. 2). Absolute masses of protein (Fig. 4) and nitrogen (Fig. 2) in each detritus correlated poorly (using data for $10 \leq \mathrm{t} \leq 150 \mathrm{~d}$ to 


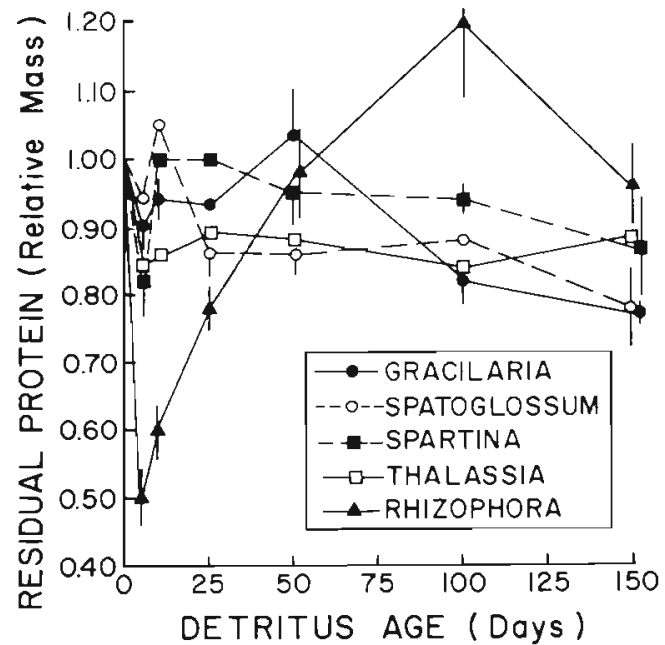

Fig. 4. Absolute mass of detrital protein during decomposition. For each detritus, protein mass is normalized to initial (Day 0) protein mass

eliminate initial leaching effects; see Rice and Tenore, 1981), yielding linear correlation coefficients of $\mathrm{r}$ (Gracilaria foliifera) $=+0.10, \mathrm{r}$ (Spartoglossum schroederi $)=-0.76, \mathrm{r}(T$. testudinum $)=0.00, \mathrm{r}($ Spartina alterniflora $)=-0.35$, and $\mathrm{r}$ (Rhizophora mangle) $=+0.05$.

Initial ( $\mathrm{t}=0 \mathrm{~d}$ ) and final $(\mathrm{t}=150 \mathrm{~d}$ ) concentrations of reactive carbohydrate, reactive phenols, and extractable humic material in the detritus are given in Table 3. Final reactive carbohydrate contents of seaweed detritus were not significantly different from initial

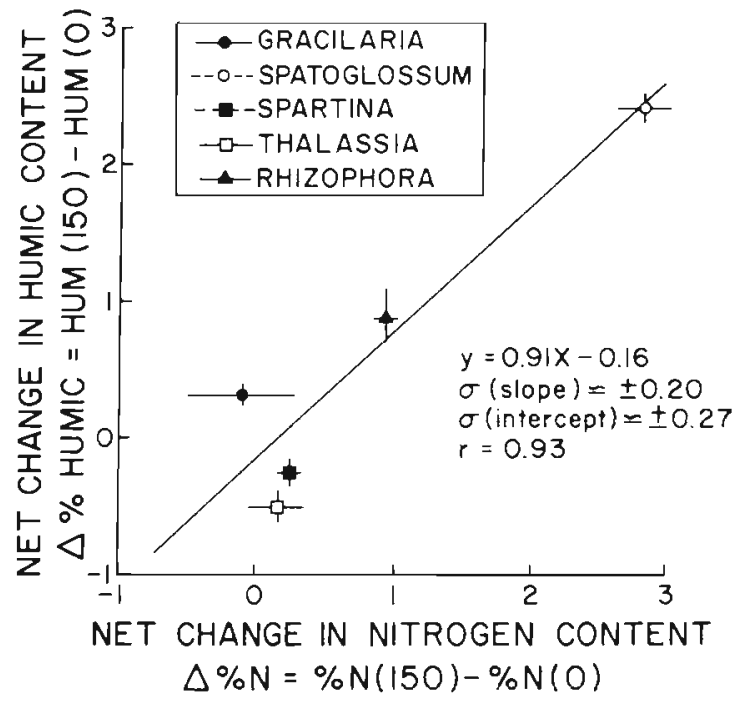

Fig. 5. Linear relation between net changes in humic substance and nitrogen content of 5 macrophyte detritus after $150 \mathrm{~d}$ of decomposition. $\Delta \%$ Humic substance and $\Delta \%$ Nitrogen (ash-free basis) are calculated from Day 0 and Day 150 data in Table 3. Uncertainties $\sigma$ in the slope and intercept of the regression line were calculated according to Bevington (1969) values; however, in vascular plant detritus, final reactive carbohydrate was as much as $70 \%$ greater than in the starting material. Reactive phenol contents of seaweed detritus were about $50 \%$ higher on D 150 than initial values; in vascular plant detritus, there were no significant differences in initial and final reactive phenol contents, except for a small decrease in Thalassia testudinum detritus. The relative contribution of extractable humic material to the ash-free dry weight of detritus decreased in the order: Rhizophora mangle $(18 \%)>$ Spartina alterniflora $>$ Thalassia testudinum $>$ Spatoglossum schoederi $>$ Gracilaria foliifera $(<1 \%)$. The net changes in \% extractable humic material $(\triangle \%$ Humics $=\%$ Humics $[t=150]-\%$ Humics $[\mathrm{t}=0])$ decreased somewhat differently: S. schroederi $(+2.42 \%)>R$. mangle $(+0.90)>G$. foliifera $(+0.33 \%)$ $>$ S. alterniflora $(-0.25 \%)>T$. testudinum $(0.51 \%)$.

The change in humic content of the detritus between D 0 and D 150 was positively and significantly related to the change in \% N (Fig. 5). Estimates of the uncertainties in the slope and intercept of the least-squares regression line (Bevington, 1969) of Fig. 5 indicate that the line is not significantly different from the straight line of unit slope passing through the origin. The detritus types were enriched with nitrogen to the same degree that they produced extractable humic materials. Correlation analysis of the relationships between nitrogen, protein, reactive carbohydrate, reactive phenol, and extractable humic substances (on both a percent and absolute mass basis) yielded no other significant correlations ( $\mathrm{p} \leq 0.05$ ).

\section{DISCUSSION}

We have demonstrated that nitrogen enrichment in aging macrophyte detritus is not synonymous with protein enrichment and that, for vascular plant material, nitrogen enrichment arises because of net transfer of nitrogen from seawater to the detrital pool. Since microbial biomass cannot account for the nitrogen increase, nitrogen must be sequestered in the nonliving portion of the detritus complex (Suberkropp et al, 1966; Odum et al., 1979; Rice, 1979; Tenore and Rice, 1980; and references cited in each). We have shown that aging produces significant amounts of reactive carbohydrates and phenols which may bind proteins in the detritus matrix (discussed below) and that there may be a substantial build-up of complex, dark-colored, abiotically synthesized humic substances. Moreover, there is strong positive correlation between the changes in $\% \mathrm{~N}$ and \% humic material in aging macrophyte detritus. Because (1) of this strong correlation, (2) the central role of nitrogen in humic material polymerization (discussed below), and (3) the 
fact that mature humic substances in marine and lacustrine sediments are often rich in organic nitrogen (discussed below), we propose that whether or not detrital nitrogen enrichment occurs depends not upon an increase in microbial biomass per se but upon the relative solubility of nitrogenous humic substances generated in the detritus-microbe complex.

In the perspective of classical organic geochemistry, detritus decomposition over a period of several months is simply the beginning of the humification process. Because organic nitrogen plays an important role in linking monomeric precursors to form humic macromolecules, higher molecular weight (MW) humic substances (kerogens, humins, and humic acids with molecular weights usually much greater than $10^{5}$ ) commonly have higher nitrogen contents than lower MW humic substances (e. g. fulvic acids) (Schnitzer, 1972). For example, fulvic acid extracts of Fucus vesiculosus detritus contained $2.37 \% \mathrm{~N}$ (ash-free basis) and humic acid extracts contained $5.60 \% \mathrm{~N}$ (ash-free basis) and humic acid extracts contained $5.60 \% \mathrm{~N}_{\mathrm{i}}$ fulvic acids from Laminaria digitata detritus contained $2.55 \% \mathrm{~N}$ and humic acids contained $6.25 \% \mathrm{~N}$ (Rashid and Prakash, 1972). In a survey of the humic acids in marine sediment samples, Rashid and King (1971) found that the nitrogen content of higher MW (> $2 \times 10^{5}$ ) components was significantly greater than that of lower MW fractions. Analogous results have been found for MW fractions of terrestrial humus (Durbach and Mehta, 1963; Ladd and Butler, 1965). About 45\% of the nitrogen extracted from Lake Ontario sediments by alkaline hydrolysis was amino acid nitrogen and at least $37 \%$ was non-amino humic nitrogen; in the alkaline-insoluble residue, only $9 \%$ of the nitrogen was definitely amino acid nitrogen and at least $54 \%$ was non-amino humic nitrogen (Kemp and Mudrochova, 1972). As humification proceeds, the organic matter becomes structurally more aromatic; and as nitrogen becomes incorporated into progressively more stable heterocyclic configurations, \% $\mathrm{N}$ may increase substantially although nitrogen availability for microbial assimilation decreases (Flaig, 1972; Jansson, 1972; Rashid and Prakash, 1972).

Chemical changes observed during the decomposition of seaweed, grass, and mangrove detritus in this study are those changes one expects to observe during humification. There were increases in reactive phenols and carbohydrates, indicating an increased capacity to bind proteins (from the detritus matrix and from microbial exudates) as amino-sugar and amino-phenol condensates (Feeney and Bostock, 1968; Sieburth and Jensen, 1969). In fact, microbial exoenzymes may be immobolized and deactivated by these reactive plant decomposition products (Benoit and Starkey, 1968; Feeney, 1970). Consequently, the proteinaceous matter exuded by even a small number of associated microbes can easily provide the nitrogen which accumulates in the humifying detritus matrix. Because polypeptide and amino nitrogen is gradually transformed into aromatic heterocyclic forms, protein and total nitrogen contents do not correlate well as aging proceeds. Conversely, the nitrogen increase not accounted for by living microbial mass (i. e. most of the nitrogen increase) is an index of the degree of humification (Fig. 5) but not of "protein enrichment".

Because of the conversion of protein nitrogen to humic nitrogen during aging, measurements of total nitrogen are of limited use in assessing the nutritional value of detritus. However, if the detritus is very young or is so easily decomposed that no accumulation of humic nitrogen occurs (e. g. in the case of Gracilaria foliifera), \% $\mathrm{N}$ may still be an index of nutritional quality. Rashid and Prakash (1972) noted that fulvic acids from seaweeds were more soluble in seawater than sedimentary fulvic acids of similar molecular weight because of the condensed, aromatic character of the latter. The low production of humic material in G. foliifera detritus (Table 3) is then intrinsically related to its decomposability and tendency to accumulate nitrogen only after a relatively long period of aging. Moreover, the persistence of G. foliifera protein in a non-humic form may be related to the high availability of $G$. foliifera detritus to the deposit-feeding polychaete Capitella capitata, compared to the relatively low availability of Spartina alterniflora detritus, even after the marsh grass detritus has aged for several months and acquired a higher \% N (Tenore and Hanson, 1980).

Estimation of protein by application of the 6.25 conversion factor to the $\% \mathrm{~N}$ extractable by dilute alkali treatment (Aronson and Machlis, 1959) may be adequate for living plant material; however, this technique cannot be confidently used to assess the protein content of aged plant detritus because dilute alkaline hydrolysis also extracts nitrogen-rich humic and fulvic acids. Treatment with dilute aqueous $\mathrm{NaOH}$ is the standard technique for humic and fulvic acid extraction and also removes hydrolysable amino-sugar and amino-phenol condensation products. Applications of the Aronson and Machlis (1959) technique to decomposing detritus derived from salt marsh plants (Haines and Hanson, 1979; Odum et al., 1979) may grossly overestimate 'protein enrichment'. Some of the nitrogen in large, newly sequestered protein molecules could persist temporarily as assimilable peptide; even in very refractory sedimentary humic materials, there may be relic 'polypeptide' regions in the humic macromolecular structure (Kemp and Mudrochova, 1972). The modified Lowry protein technique developed for this study is sufficiently precise to show that detritus 
nitrogen is not necessarily protein nitrogen. However, analytical techniques capable of accurately determining protein in these rather complex matrices (perhaps a dye-binding method) must be developed to pursue the details of a nitrogen mass balance.

Considering our present state of knowledge of the dynamics of the detritus-microbe association, the chemistry of sedimentary humic material, and the observations cited above, we propose the following mechanism for nitrogen accumulation in detritus:

(1) After initial leaching of soluble materials from fresh detritus, microbial enzymes depolymerize the detritus substrate producing reactive carbohydrates, phenols, small peptides, and amino acids.

(2) These reactive carbohydrates and phenols condense with polypeptides and amino acids to produce nitrogenous geopolymers.

(3) Microbes associated with detritus assimilate dissolved nitrogen from seawater for protein (including exoenzyme) synthesis.

(4) Exoenzymes and other proteinaceous materials exuded by microbes condense with reactive carbohydrates and phenols in the humifying detritus. If the condensation products are not easily solubilized in seawater, the detritus particle becomes enriched with humic nitrogen.

(5) As humification proceeds, detritus nitrogen is gradually transformed from relatively labile aminosugar, amino-phenol, and polypeptide forms into chemically recalcitrant (and progressively less assimilable) heterocyclic aromatic forms typical of mature sedimentary humic material.

This mechanism emphasizes that nitrogen accumulation in detritus is part of the more general humification process. Moreover, bacteria are considered to be a $g$ e $n t s$ of nitrogen enrichment, their role as nitrogen r eservoirs being much less important inasmuch as they contribute little to total detritus nitrogen. Finally, this model requires and the de facto persistence of nitrogenous sedimentary humic substances indicates that there must be an upper limit beyond which nitrogen enrichment cannot be equated with increasing nutritional value to benthic detritivores

There is obviously a need for more detailed study of detrital nitrogen and its role in detritus-based ecosystems. In this paper we have implied, as have other investigators (Feeney, 1970; Suberkropp et al., 1976; Odum et al., 1979), that most or a least a large portion of the nitrogen accumulated in organic detritus may not be nutritionally available to macroconsumers and that, for some detritus, nitrogen enrichment is perhaps more of an index of the degree of humification than of protein enrichment. Insofar as this hypothesis is true, microbes associated with plant detritus may indeed constitute the principal reservoir of assimilable detrital nitrogen, at least in decay-resistant detritus, as originally proposed by Newell (1965) for fecal detritus. Concomitant nitrogen enrichment in plant detritus may simply indicate the degree to which the organic matrix has been enzymatically depolymerized to smaller, assimilable molecules or "available calories" (Tenore, 1981). The question of the relative importance of detrital microflora as protein reservoirs or as agents converting complex substrates to assimilable products is of basic importance in detrital trophic energetics. Future studies of the nitrogen problem should include detailed chemical studies of the detritus itself as well as investigations of the biological assimilability of those products.

Acknowledgements. I am grateful to Dr. Kenneth R. Tenore, who introduced me to and guided my early thinking on the detritus nitrogen problem, and to Dr. Herbert L. Windom for providing the research opportunity, guidance, and occasional restraining hand that made this study possible. Also I have learned much about the nitrogen problem through discussions with Drs. Glenn Lopez, Lawrence M. Mayer, Steven Y. Newell, and William E. Odum. Dr. J. Helmut Reuter provided much valuable advice on analysis of humic substances and also donated the Satilla River humic acid standard, and Mr. Neal W. Phillips critically reviewed the modified Lowry protein method. Critical reviews by 3 anonymous referees were of inestimable help in refining the manuscript. Ms. Katherine Holley, Ms. Olga Kurty and Ms. Joan Scott assisted in manuscript preparation. This research was supported by funds from the National Science Foundation grant numbers OCE7720244 and OCE78-25862, the Skidaway Institute of Oceanography, and the Research Foundation of the State University of New York.

\section{LITERATURE CITED}

Aronson, J. M., Machlis, L. (1959). The chemical composition of the hyphal walls of the fungus Allomyces. Am. J. Bot. 46: 292-300

Benoit, R. D., Starkey, R. L. (1968). Enzyme inactivation as a factor in the inhibition of decomposition of organic matter by tannins. Soil Sci. 105: 203-209

Bevington, P. R. (1969). Data reduction and error analysis for the physical sciences, McGraw-Hill, New York

Boyd, C. E., Goodyear, C. P. (1971). Nutritive quality of food in ecological systems. Arch. Hydrobiol. 69: 256-270

Christian, R. R., Wetzel, R. L. (1978). Interaction between substrate, microbes, and consumers of Spartina detritus in estuaries. In: Wiley, M. L. (ed.) Estuarine interactions. Academic Press, New York, pp. 93-144

Degens, E. T., Reuter, J. H. (1962). Analytical techniques in the field of organic geochemistry. In: Columbo, U., Hobson, G. D. (eds.) Advances in organic geochemistry. Macmillan, New York, pp. 377-402 
Dubois, M., Gilles, K. A., Hamilton, J. K., Rebers, P. A., Smith, F. (1956). Colorimetric method for the determination of sugars and related substances. Anal. Chem. 28: 350-356

Durbach, P., Mehta, N. C. (1963). The chemistry of soil humic substances. Soils Fertil. 16: 293-300

Feeney, P. (1970). Seasonal changes in oak leaf tannins and nutrients as a cause of spring feeding by winter moth caterpillars. Ecology 51: 565-581

Feeney, P., Bostock, H. (1968). Seasonal changes in the tannin content of oak leaves. Phytochemistry 7: 871-880

Fell, J. W., Cefalu, R. C., Master, I. M., Tallman, A. S. (1975). Microbial activities in the mangrove (Rhizophora mangle L.) leaf detrital system. Proc. Int. Symp. Biol. and Manag. of Mangrove, Hawaii, pp. 661-679

Fenchel, T. (1972). Aspects of decomposer food chains in marine benthos. Verh. dt. zool. Ges. 65: 14-22

Flaig, W. (1972). An introductory review on humic substances: aspects of research on their genesis, their physical and chemical properties, and their effect on organisms. In: Povoldeo, D., Golterman, H. L. (eds.) Humic substances. Centre for Agricultural Publishing and Documentation, Wageningen, pp. 19-42

Haines, E. B., Hanson, R. B. (1979). Experimental degradation of detritus made from the salt marsh plants Spartina alterniflora, Salicornia virginica, and Juncus roemerianus. J. exp. mar. Biol. Ecol, 40: 27-40

Harborne, J. B. (1964). Biochemistry of phenolic compounds, Academic Press, New York

Hargrave, B. T. (1970a). The effect of deposit-feeding amphipods on the metabolism of benthic microflora. Limnol. Oceanogr. 15: 21-30

Hargrave, B. T. (1970b). The utilization of benthic microflora by Hyalella azteca (Amphipoda), J. Anim. Ecol. 39; $427-437$

Hargrave, B. T. (1976). The central role of invertebrate feces in sediment decomposition. In: Anderson, J. J., Macfadyen, A. (eds.) The role of terrestrial and aquatic organisms in decomposition processes. Blackwell, Oxford, pp 301-321

Harrison, P. G., Mann, K. H. (1975). Detritus formation from eelgrasss (Zostera marina L.): the relative effects of fragmentation, leaching, and decay. Limnol. Oceanogr. 20: 924-934

Hobbie, J. E., Lee, C. (1980). Microbial production of extracellular material: importance in benthic ecology. In: Tenore, K. R., Coull, B. C. (eds.) Marine benthic dynamics. Univ, of South Carolina Press, Columbia, pp. 341-346

Jansson, S. L. (1972). Role of humus formation and decomposition in the terrestrial nitrogen cycles. In: Povoledo, D., Golterman, H. L. (eds.) Humic substances. Centre for Agricultural Publishing and Documentation, Wageningen, pp. 123-135

Kemp, A. L. W., Mudrochova, A. (1972). Nitrogen in sedimented organic matter from Lake Ontario. In: Povoledo, D., Golterman, H. L. (eds) Humic substances. Centre for Agricultural Publishing and Documentation, Wageningen, pp. 137-157

King, H. G. C., Heath, G. W. (1967). The chemical analysis of small samples of leaf material and the relationship between disappearance and composition of leaves. Pedobiologia 7: 192-197

Ladd, J. N., Butler, J. H. A. (1965). Comparison of some properties of soil humic acids and synthetic phenolic polymers incorporating amino derivatives. Aust. J. Soil Res, 4: $41-54$

Lowry, O. H., Rosebrough, N. J., Farr, A. L., Randall, R. J.
(1951). Protein measurement with the Folin phenol reagent. J. biol. Chem. 193: 265-275

Mann, K. H. (1972). Macrophyte production and detritus food chains in coastal waters. Memorie Ist. ital. Idrobiol. 29 (Suppl.): 353-383

Marsh, D. H., Odum, W. E. (1979). Effect of suspension and sedimentation on the amount of microbial colonization of salt marsh detritus. Estuaries 2: 184-188

Newell, R. (1965). The role of detritus in the nutrition of two marine deposit feeders, the prosobranch Hydrobia ulvae and the bivalve Macoma balthica. Proc. zool. Soc. 144 : $25-45$

Newell, S. Y., Hicks, R. (in press). Direct count estimates of fungal and bacterial biovolume in dead leaves of smooth cordgrass, Spartina alterniflora. Estuaries

Odum, W. E., Kirk, P. W., Zieman, J. C. (1979). Non-protein nitrogen compounds associated with particles of vascular plant detritus. Oikos 32: 363-367

Pirie, N. W. (1955). Proteins. In: Paech, K., Tracey, V. (eds.) Modern methods of plant analysis, Vol. 4. Springer, Heidelberg, pp. 314-367

Ragan, M. A., Craigie, J. S. (1978). Phenolic compounds in brown and red algae. In: Hellebust, J. A., Craigie, J. S. (eds.) Handbook of phycological methods. Cambridge Univ. Br., Cambridge, pp. 157-179

Rashid, M. A., King, L. H. (1971). Chemical characteristics of fractionated humic acids associated with marine sediments. Chem. Geol. 7: 37-43

Rashid, M. A., Prakash, A. (1972). Chemical characteristics of humic compounds isolated from some decomposed marine algae. J. Fish. Res. Bd Can. 29: 55-60

Rice, D. L. (1979). Trace element chemistry of aging marine detritus derived from coastal macrophytes. Ph. D. Dissertation, Georgia Institute of Technology, Atlanta

Rice, D. L., Tenore, K. R. (1981). Dynamics of carbon and nitrogen during the decomposition of detritus derived from estuarine macrophytes. Estuar coast. Shelf Sci. 13: $681-690$

Roman, M. R. (1977). Feeding of the copepod, Acartia tonsa, on the diatom Nitzschia closterium and brown algae (Fucus vesiculosus) detritus. Mar. Biol. 42: 149-155

Rublee, P., Cammen, L., Hobbie, J. (1978), Bacteria in a North Carolina salt marsh: standing crop and importance in the decomposition of Spartina alterniflora, Univ. of North Carolina Sea Grant, Raleigh

Russell-Hunter, W. D. (1970). Aquatic productivity, Macmillan, New York

Schnitzer, M. (1972). Chemical, spectroscopic, and thermal methods for the classification and characterization of humic substances. In: Povoledo, D., Golterman, H. L. (eds.) Humic substances. Centre for Agricultural Publishing and Documentation, Wageningen, pp. 293-310

Sieburth, J. M. (1975), Microbial seascapes, University Park Press, Baltimore

Sieburth, J. M., Jensen, A. (1969). Studies on algal substances in the sea. II. The formation of Gelbstoff (humic material) by exudates of Phaeophyta. J. exp. mar. Biol. Ecol. 3: 275-289

Strickland, J. D. H., Parsons, T. R. (1972). A practical handbook of seawater analysis, Fisheries Research Board of Canada, Ottawa

Suberkropp, K., Godshalk, G. L., Klug, M. J. (1976). Changes in the chemical composition of leaves during processing in a woodland stream. Ecology 57 : 720-727

Tenore, K. R. (1981). Organic nitrogen and caloric content of detritus. I. Utilization by the deposit-feeding polychaete, Capitella capitata. Estuar. coast. Shelf Sci. 12: 39-47 
Tenore, K. R., Hanson, R. B. (1980). Availability of detritus of different types and ages to a polychaete macroconsumer, Capitella capitata. Limnol. Oceanogr. 25: 553-558

Tenore, K. R., Rice, D. L. (1980). Trophic factors affecting secondary production of deposit feeders. In: Tenore, K. R.,
Coull, B. C. (eds.) Marine benthic dynamics. Univ. of South Carolina Press, Columbia, pp. 325-340

Wiebe, W. J., Pomeroy, L. R. (1972). Microorganisms and their association with aggregates and detritus in the sea: a microscopic study. Memorie Ist, ital. Idrobiol. 29 (Suppl.): $325-352$

This manuscript was submitted to the editor; it was accepted for printing on April 15, 1982 